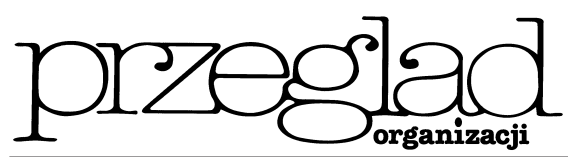

\title{
Alianse w polskich przedsiębiorstwach telefonif stacjonarnej
}

https://doi.org/10.33141/po.2005.06.07

Przegląd Organizacji, Nr 6 (785), 2005, ss. 29-32

www.przegladorganizacji.pl

Remigiusz Kozłowski Towarzystwo Naukowe Organizacji i Kierownictwa (TNOiK)

\section{Wstęp \\ W} e współczesnej gospodarce przedsiębiorstwa nie tylko konkurują między sobą, ale również podejmują współpracę. Zjawisko to będzie się nasilało w związku z postępującymi procesami globalizacji ${ }^{1)}$. Do głównych przyczyn łączenia się przedsiębiorstw umowami aliansowymi zalicza się: majacy charakter akceleracyjny postęp techniczny w zakresie technologii informacyjnych (zwłaszcza w branży telekomunikacyjnej), transportowych ${ }^{2)}$ oraz unifikację potrzeb i upodobań klientów ${ }^{3)}$. Przedsiębiorstwa zawierając porozumienia aliansowe chcą osiągnąc określone cele, głównie strategiczne. Praktyka pokazała, że nie zawsze udaje się je zrealizować w stopniu zadowalajacym. Alianse niosa ze soba szanse na utrzymanie się na rynku i rozwój przedsiębiorstw, ale również niebezpieczeństwa. Porozumienia te na rynku usług telekomunikacyjnych w większości przypadków nie są związkami trwałymi ${ }^{4}$. Dotyczy to zarówno przedsiębiorstw dużych, jak również małych i średnich.

Celem publikacji jest określenie zakresu wykorzystania możliwości zawierania aliansów przez krajowych operatorów telefonii stacjonarnej. Zostanie on zrealizowany poprzez identyfikację zawartych aliansów oraz planów analizowanych przedsiębiorstw w zakresie zawierania porozumień z innymi podmiotami. Określone zostaną także motywy skłaniające lub zniechęcające firmy telekomunikacji stacjonarnej do zawiązywania aliansów. Pozwoli to na bardziej skuteczne poszukiwanie partnerów i prowadzenie negocjacji, co może zaowocować większą liczbą takich porozumień w przyszłości.

\section{Rola aliansów we współczesnej gospodarce}

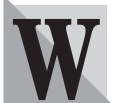

literaturze spotyka się wiele różnych definicji aliansów. Według M. Romanowskiej polegają one na „[...] współdziałaniu dwóch lub więcej przedsiębiorstw, które są aktualnymi lub potencjalnymi konkurentami, w celu realizacji wspólnego przedsięwzięcia lub prowadzenia określonej działalności" ${ }^{5}$. W opracowaniach naukowych wyróżnia się również pojęcie aliansu strategicznego. Jako uzasadnienie takiego podziału podawane jest, że nie wszystkie porozumienia kooperacyjne radykalnie zmieniają sytuację w sektorze ${ }^{6)}$. Tylko te, które powo- dują zmianę układu konkurencyjnego są określane jako strategiczne.

Niektórzy autorzy szerzej definiują alianse. J. Cygler określa alianse jako ,[...] długoterminowe i celowe umowy między przedsiębiorstwami, zawarte na zasadach partnerstwa, adekwatności czerpanych z sojuszu korzyści, przy zachowaniu odrębności organizacyjnej stron"7). W rozumieniu tej definicji alianse mogą być zawierane nie tylko z potencjalnymi konkurentami, ale także np. $\mathrm{z}$ dostawcami. W niniejszym opracowaniu przyjęta jest „szersza” definicja aliansu mieszcząca w sobie również alianse strategiczne.

Istnieje bardzo dużo potencjalnych motywów zawierania aliansów ${ }^{8}$. Alianse moga przybierać różne formy. Czasami polegają tylko na udzieleniu licencji czy zawarciu umów o współpracy (oficjalnych albo utajnionych ${ }^{9)}$ ) lub franchisingu. Niekiedy przybieraja formę częściowego wykupu udziałów partnera ${ }^{10)}$.

Osiagnięcie sukcesu przez przedsiębiorstwa powiązane za pomoca aliansów nie jest łatwe. Wyniki wielu przeprowadzonych badań potwierdzają tę tezę ${ }^{11)}$. Okazało się także, że efektywność zawartych aliansów zależy od odległości geograficznej partnerów. Wiąże się z pewnymi wzorcami zachowań, prowadzenia działalności gospodarczej, a więc szeroko rozumianą kulturą. Mniejszy dystans dzielący partnerów wpływał na większe prawdopodobieństwo osiągnięcia sukcesu przez obydwu partnerów ${ }^{12)}$. Średnie i małe firmy wybieraja partnerów bliżej niż przedsiębiorstwa duże ${ }^{13)}$.

Warunkiem koniecznym osiągnięcia sukcesu przez przedsiębiorstwa powiązane aliansem są odpowiednio skonstruowane umowy aliansu, a następnie prawidłowe zarządzanie. Istnieje wiele czynników umożliwiających sukces aliansów ${ }^{14)}$.

Oprócz korzyści istnieją także pewne ryzyka związane $\mathrm{z}$ zawarciem porozumienia aliansowego ${ }^{15)}$. W przypadku, gdy partnerzy wnoszą niejednakowe udziały, niebezpieczeństwa znacznie wzrastają. W takich przypadkach może wystąpić sytuacja, w której jeden z partnerów wykorzystuje alians do osłabienia lub całkowitego uzależniania innych od siebie. W aliansach komplementarnych szczególnie niebezpieczne jest uzależnienia się wzajemne partnerów do tego stopnia, że nie są oni zdolni do samodzielnego funkcjonowania na rynku. Dużym zagrożeniem może być jednostronny transfer wiedzy, który powoduje po pewnym czasie utratę przewagi konkurencyjnej na rzecz partnera. 
Również porozumienia zawierane pomiędzy przedsiębiorstwami o różnych potencjałach i pozycji konkurencyjnej (alianse niesymetryczne) mogą doprowadzić w dłuższej perspektywie do wyeliminowania słabszego partnera z rynku ${ }^{16}$. Często taka sytuacja ma miejsce $\mathrm{w}$ aliansach firm krajowych $\mathrm{z}$ międzynarodowymi. W literaturze wymienia się jeszcze dużo innych przyczyn niepowodzeń aliansów ${ }^{17}$.

\section{Alianse w przedsiębiorstwach telekomunikacyjnych}

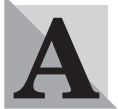

lianse najczęściej powstają w sektorach zaawansowanych (wysokich) technologiii $^{18)}$. Branża telekomunikacyjna już w latach 80. ub. wieku charakteryzowała się wyjątkową liczbą powiązań między poszczególnymi światowymi operatorami ${ }^{19)}$.

W efekcie konwergencji technologicznej i liberalizacji rynku pojawiło się bardzo wiele nowych przedsiębiorstw działających w branży telekomunikacyjnej ${ }^{20)}$. Taka sytuacja wzmogła walkę konkurencyjną oraz zmusiła do poszukiwania szans na rozwój w aliansach zarówno z innymi operatorami, jak i m.in. z firmami produkującymi sprzęt, tworzącymi oprogramowanie czy świadczącymi usługi internetowe. Firmy telekomunikacyjne w ten sposób uzyskiwały szansę na dynamiczne rozszerzanie oferty usług oraz redukcję ryzyka wchodzenia w nowe obszary geograficzne lub nowe specyficzne grupy usług.

Cechą aliansów zawieranych przez firmy telekomunikacyjne jest ich nietrwałośćc1). Przyczyn tej sytuacji upatruje się w oddziaływaniu wyjątkowo turbulentnego otoczenia. Szybkie i głębokie zmiany otoczenia powodują ciągłą zmienność zasobów, jakie są potrzebne do realizacji potrzeb klientów. Przedsiębiorstwa w momencie zawierania aliansu dysponują określonymi specjalistami, doświadczeniem, urządzeniami itp., które w tym czasie mogą zapewnić osiągnięcie określonego celu. Jednak w warunkach turbulencyjności otoczenia stan ten szybko się zmienia i wcześniej zawarte porozumienie nie gwarantuje sukcesu. Jeżeli nie zostaną wprowadzone korekty do zasad funkcjonowania aliansu, to zakończy się on niepowodzeniem.

\section{Charakterystyka badanych przedsiębiorstw} ateriał empiryczny do analizy wykorzystania możliwości zawierania aliansów przez operatorów telefonii stacjonarnej został zebrany przez autora za pomoca takich technik badawczych, jak: ankieta, wywiad bezpośredni, analiza informacji zawartych w czasopiśmiennictwie ekonomiczno-technicznym, a także obserwacja uczestnicząca. Do badań wybrano wszystkie krajowe firmy telefonii stacjonarnej, które spełniały łącznie następujące kryteria doboru próby:

- posiadały koncesję na prowadzenie działalności telekomunikacyjnej zawierająca zapis pozwalający na oferowanie usług telefonii stacjonarnej;

- do końca 2001 r. rozpoczęły sprzedaż usług telekomunikacyjnych, która stanowiła najważniejszą działalność firmy;

- kierowały ofertę usług do klientów zewnętrznych (a nie tylko do np. podmiotu nadrzędnego).

Łącznie badaniami objęto 22 przedsiębiorstwa $\mathrm{z}$ terenu całej Polski zatrudniające ponad 71 tysięcy pracowników oraz obsługujace prawie 11 milionów czynnych łączy telekomunikacyjnych. Badania zostały przeprowadzone $\mathrm{w}$ okresie od września do grudnia 2002 r.

Wszystkie potrzebne informacje do badań udało się uzyskać z 16 przedsiębiorstw, co stanowi około $73 \%$ całej zbiorowości badanej. Ze względu na specyfike badanych firm dokonano podziału na następujące cztery grupy przedsiębiorstw (tabela) ${ }^{22}$.

\section{Wyniki badań empirycznych}

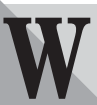

segmencie telefonii stacjonarnej występuje duża liczba stosunkowo małych operatorów telekomunikacyjnych posiadajacych niewielki udział w rynku. Pozycję zdecydowanego lidera nadal utrzymuje operator narodowy (posiadajacy powyżej 90\% rynku). Obszary działania poszczególnych konkurentów TP SA nie pokrywają się (poza kilkoma przypadkami). Taka sytuacja może sprzyjać zawieraniu aliansów. Przeprowadzone badania dotyczyły m.in. już zawartych aliansów oraz zamierzeń operatorów telefonii stacjonarnej w tym zakresie.

$\mathrm{Na}$ rysunku 1 przedstawione zostały informacje o już zawartych aliansach przez badane przedsiębiorstwa oraz ich planach w odniesieniu do tej problematyki.

Odpowiedzi respondentów są dosyć zaskakujące. Aż dziesięciu operatorów nie zawarło żadnego aliansu i nie zamierzało tego robić w przyszłości. Do przeciwników wiązania swojej działalności z innymi zaliczały się głównie mniejsze przedsiębiorstwa. W tej grupie znalazły się wszystkie bardzo małe firmy i przeważająca część małych.

Tab. Charakterystyka badanych przedsiębiorstw pod względem liczebności zatrudnionych

\begin{tabular}{|c|c|c|c|c|}
\hline $\begin{array}{c}\text { Grupa } \\
\text { przedsiębiorstw }\end{array}$ & $\begin{array}{c}\text { Liczba } \\
\text { zatrudnionych }\end{array}$ & Symbol & $\begin{array}{c}\text { Liczebność firm } \\
\text { (N) }\end{array}$ & $\begin{array}{c}\text { Udział w lącznej liczbie } \\
\text { przebadanych firm (\%) }\end{array}$ \\
\hline bardzo małe & do 19 & BM & 4 & 25,0 \\
\hline małe & od 20 do 99 & M & 6 & 37,5 \\
\hline średnie & od 100 do 499 & S & 4 & 25,0 \\
\hline duże & powyżej 499 & D & 2 & 12,5 \\
\hline \multicolumn{2}{|c|}{ Razem: } & $\mathbf{1 6}$ & $\mathbf{1 0 0}$ \\
\hline
\end{tabular}

Źródło: opracowanie na podstawie badań własnych. 


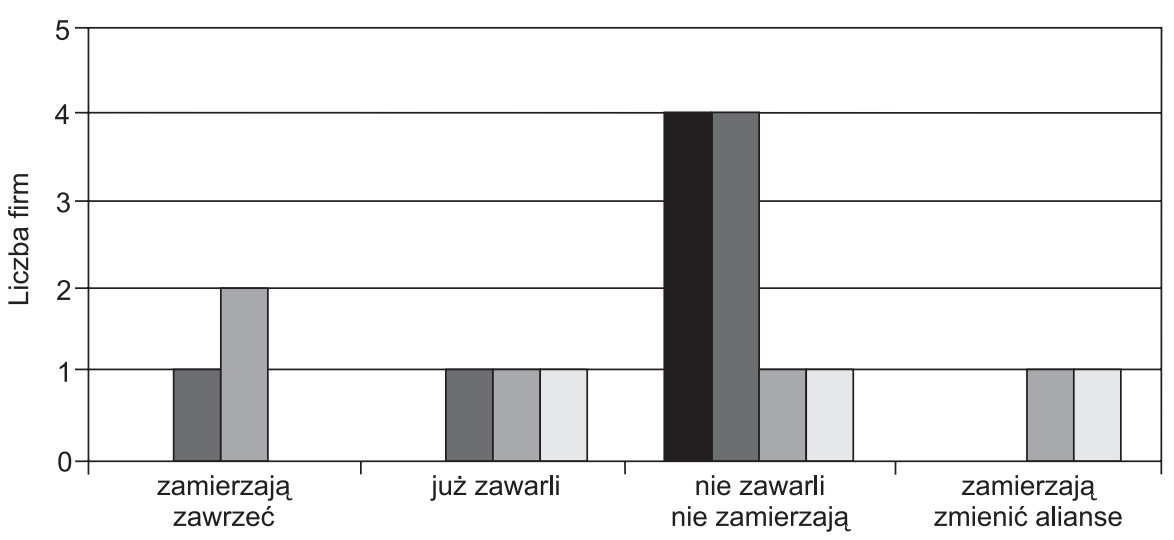

bardzo małe $\square$ małe $\square$ średnie $\square$ duże

Rys. 1. Alianse operatorów telefonii stacjonarnej w Polsce

Źródło: opracowanie na podstawie badań własnych.

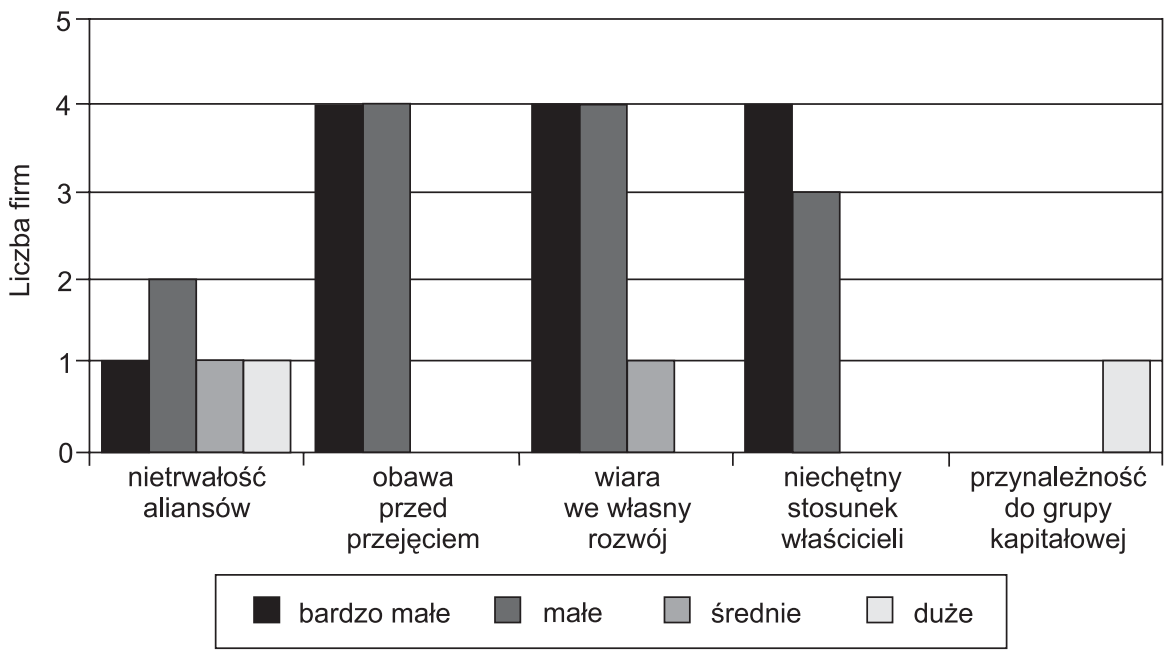

Rys. 2. Przyczyny niezawierania aliansów przez operatorów telefonii stacjonarnej w Polsce

Źródło: opracowanie na podstawie badań własnych.

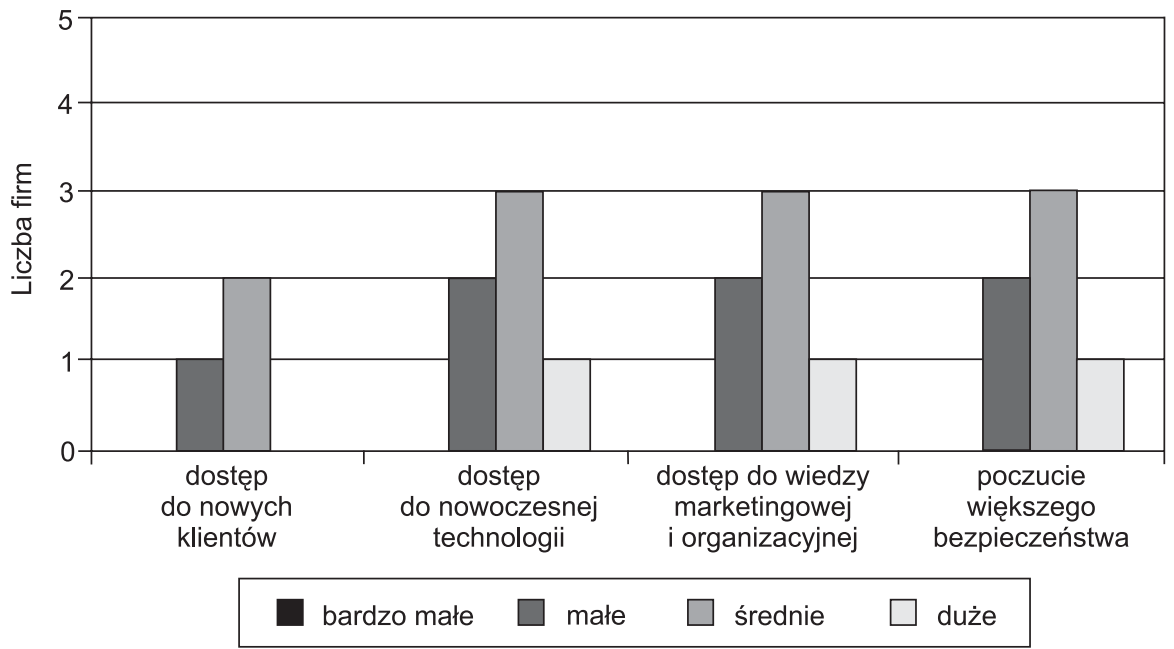

Rys. 3. Przyczyny zawierania aliansów przez krajowe przedsiębiorstwa telefonii stacjonarnej w Polsce

Źródło: opracowanie na podstawie badań własnych.
W grupie większych przedsiębiorstw sytuacja była odmienna. Większość badanych firm średnich była zainteresowana zawieraniem aliansów. W tej grupie operatorów zauważyć można także pewną aktywność związaną z zamiarami zmiany już zawartych porozumień.

Z powyżej zaprezentowanych danych wynika obraz dosyć dynamicznego rynku telekomunikacyjnego. Znaczna część badanych firm zamierzała zawrzeć alianse lub je zmienić. Do przedsiębiorstw reprezentujących taki sposób działania na rynku zaliczały się większe firmy telekomunikacyjne - przede wszystkim średni i duzi operatorzy.

Jednak niepokojacy jest fakt braku zainteresowania większości badanych przedsiębiorstw innymi operatorami. Na rysunku 2 przedstawione zostały informacje dotyczace przyczyn, które zniechęcały firmy telefonii stacjonarnej do zawierania aliansów. Odpowiedzi udzielane były tylko przez te przedsiębiorstwa, które nie zawarły i nie zamierzały łaczyć sie z innymi podmiotami za pomocą porozumień. Każde $\mathrm{z}$ nich mogło podać dowolna liczę przyczyn niechęci do zawierania aliansów.

Wszystkie najmniejsze $\mathrm{z}$ badanych firm zniechęcała do zawierania aliansów $\mathrm{z}$ innymi przedsiebiorstwami obawa przed przejęciem przez potencjalnego partnera. Takie wyniki można wytłumaczyć poczuciem zagrożenia współpraca w sytuacji małego potencjału tych operatorów. Jednocześnie dotychczasowy dynamiczny wzrost bardzo małych przedsiębiorstw pozwalał im wierzyć we własne siły i w dalszy niezależny rozwój. Właściciele, często założyciele tych firm, byli przeciwni zawieraniu aliansów. Wierzyli oni głęboko, że sami są w stanie dalej rozwijać własne przedsiębiorstwa. W tej grupie firm niewielką wagę przywiązywano do potencjalnej nietrwałości aliansów. 
Przedsiębiorstwa małe obawiały się przejęcia i wierzyły w samodzielny rozwój. W tej grupie operatorów właściciele nie sprzyjali zawieraniu aliansów. Większą rolę przywiązywały przedsiębiorstwa małe do nietrwałości tych porozumień niż najmniejsze firmy.

Średni operatorzy niechętni aliansom wierzyli w samodzielny rozwój oraz obawiali się nietrwałości porozumień. Z kolei duże przedsiębiorstwa nie szukały partnerów w związku z przynależnością do stabilnej grupy kapitałowej lub obawiały się szybkiego zerwania aliansu.

Na rysunku 3 przedstawione zostały wyniki badań empirycznych dotyczące czynników skłaniających badane przedsiębiorstwa do łączenia się z innymi podmiotami za pomoca porozumień. Odpowiedzi uzyskane zostały tylko od operatorów, którzy już zawarli alians lub zamierzają to zrobić.

Dla wszystkich firm małych, średnich i dużych, które były zwolennikami zawierania aliansów czynnikami skłaniającymi do takiego rodzaju współpracy były: dostęp do nowoczesnej technologii i wiedzy marketingowo-organizacyjnej oraz poczucie większego bezpieczeństwa. Dostęp do nowych klientów w ten sposób chciały sobie zapewnić wszystkie analizowane firmy średnie i tylko jedna mała.

\section{Podsumowanie}

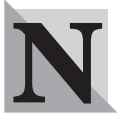

a podstawie przeprowadzonych przez autora badań i analiz udało się sformułować następujące wnioski:

- istnieje bardzo wyraźny związek wielkości badanych przedsiębiorstw ze skłonnością do zawierania aliansów; im większy operator telefonii stacjonarnej, tym chętniej zawierał porozumienia lub zamierzał to robić w przyszłości;

- najistotniejszymi czynnikami zniechęcającymi operatorów do zawierania porozumień były: obawy zwiazane z możliwością ewentualnego przejęcia przez partnera, niechętny stosunek właścicieli oraz wiara w możliwość dalszego samodzielnego rozwoju;

- firmy telefonii stacjonarnej zawierały alianse głównie w celu uzyskania dostępu do nowych technologii telekomunikacyjnych, fachowej wiedzy organizacyjnej i marketingowej oraz poczucia większego bezpieczeństwa.

Zaprezentowane wyniki przeprowadzonych przez autora badań przedstawiają zróżnicowane koncepcje dalszego rozwoju krajowych firm telefonii stacjonarnej. Część badanych przedsiębiorstw widzi swoją przyszłość w powiązaniu własnej działalności z innymi podmiotami i w ten sposób zamierza zwiększać i unowocześniać ofertę usług telekomunikacyjnych oraz zdobywać nowych klientów.

Niepokojący jest fakt braku gotowości do współpracy ze strony wielu (liczbowo przeważającej części) operatorów. Firmom tym będzie bardzo trudno nadążyć za szybkim rozwojem technologii telekomunikacyjnych, rosnącymi potrzebami klientów i ciągle nasilającą się konkurencją.

dr inż. Remigiusz Kozłowski Katedra Zarządzania Przedsiębiorstwem Uniwersytetu Łódzkiego
PRZYPISY

1) B. HAUS, Wspótdziatanie gospodarcze przedsiębiorstwa a alianse strategiczne, [w:] K. KOWALSKA, Alianse strategiczne przedsiębiorstw, Wyższa Szkoła Biznesu w Dąbrowie Górniczej, Dąbrowa Górnicza 2001, s. 9.

2) J. CYGLER, Alianse strategiczne, Difin, Warszawa 2002, s. 11 .

3) Unifikacja upodobań i potrzeb klientów jest charakterystyczna cecha dla usług telekomunikacyjnych, klienci na całym świecie mają niemalże identyczne preferencje co do charakteru i specyfiki tych usług.

4) T. WOLIŃSKI, Trwatość aliansów strategicznych na globalnym rynku ustug telekomunikacyjnych, „Organizacja i Kierowanie" nr 2 (100) 2000, s. 39.

5) M. ROMANOWSKA, Alianse strategiczne przedsiębiorstw, PWE, Warszawa 1997, s. 8.

6) H. CHWISTECKA-DUDEK, W. SROKA, Alianse strategiczne. Problemy teorii $i$ dylematy praktyki, Wydawnictwo Profesjonalnej Szkoły Biznesu, Kraków 2002, s. 25.

7) J. CYGLER, Alianse strategiczne, Difin, Warszawa 2002, s. 32 .

8) Szerzej na ten temat [w:] M. GAWINECKI, W.M. GRUDZEWSKI, W. ROGOWSKI, Alianse strategiczne przedsiębiorstw w warunkach polskich, „Ekonomika i Organizacja Przedsiebiorstwa" nr 3 (602) 2000, s. 3; M. ROMANOWSKA, Alianse strategiczne przedsiębiorstw, PWE, Warszawa 1997, s. 42-61; H. CHWISTECKA-DUDEK, W. SROKA, Alianse strategiczne. Problemy teorii $i$ dylematy praktyki, Wydawnictwo Profesjonalnej Szkoły Biznesu, Kraków 2002, s. 32-40.

9) Alianse nieformalne mają miejsce w sytuacjach, kiedy nie można zawrzeć oficjalnie porozumienia z powodu niezgodności $\mathrm{z}$ istniejacym prawem, np. przepisami antymonopolowymi.

10) Opracowano na podstawie: H. CHWISTECKA-DUDEK, W. SROKA, Alianse strategiczne. Problemy teorii i dylematy praktyki, Wydawnictwo Profesjonalnej Szkoły Biznesu, Kraków 2002, s. 91-95; M. ROMANOWSKA, Alianse strategiczne przedsiębiorstw, PWE, Warszawa 1997, s. $80-89$.

11) E.R. STAFFORD, Using Co-operative Strategies to make Alliances Work, „Long Range Planning” 1994, nr 3.

12) J. BLEEKE, D. ERNST, Collaborating to Compete. Using Strategic Alliances and Acquisition in the Global Marketplaces, John Wiley and Sons 1993, s. 20.

13) S. URBAN, S. VENDEMINI, European Strategic Alliances. Co-operative Corporate Strategies in the New Europe, Blackwell 1992, s. 161.

14) Szerzej na ten temat [w:] D. LITTER, F. LEVERICK, Joint Ventures for Products Development: Learning from Experience, Long Range Planning" 1995, nr 3 [za:] M. ROMANOWSKA, Alianse strategiczne przedsiebiorstw, PWE, Warszawa 1997, s. 138-139.

15) A. SIKORSKI, Alianse strategiczne-szanse $i$ zagrożenia, „Organizacja i Kierowanie” nr 5/92, s. 74-76.

16) M. ROMANOWSKA, Alianse strategiczne przedsiębiorstw, PWE, Warszawa 1997, s. 8.

17) Szerzej na ten temat [w:] C.L. HUNG, Strategic Business Alliances between Canada and the Newly Industrialized Countries of Pacific Asia, „Management International Review" 1994, vol. 32 , nr 4, s. 354 .

18) D. MORRIS, M. HARGERT, Trends in Collaborative Agreements, „Columbia Journal of World Business”, lato 1987, s. 18.

19) G. DEVLIN, M. BLEACKLEY, Strategic Alliances - Guidlines for Success, „Long Range Planning” 1988, nr 5.

20) T. WOLIŃSKI, Trwatość aliansów strategicznych na globalnym rynku ustug telekomunikacyjnych, „Organizacja i Kierowanie" nr 2 (100) 2000, s. 40-41.

21) Szerzej na ten temat [w:] T. WOLIŃSKI, Trwatość aliansów strategicznych na globalnym rynku ustug telekomunikacyjnych, „Organizacja i Kierowanie” nr 2 (100) 2000, s. 39.

22) Dokładny opis tworzenia grup zamieszczony jest [w:] $\mathrm{S}$. LACHIEWICZ, R. KOZŁOWSKI, Analysis of Some Structure-forming Factors on the Basis of Fixed Telecommunications Enterprises, „Management” vol. 8, nr 1, Zielona Góra 2004, s. 165-166. 